Article

\title{
Wheat Varietal Diversification Increases Ethiopian Smallholders' Food Security: Evidence from a Participatory Development Initiative
}

\author{
Elisabetta Gotor 1,*D, Muhammed Abdella Usman ${ }^{2}{ }^{(D}$, Martina Occelli ${ }^{3}$, Basazen Fantahun ${ }^{3,4}$, Carlo Fadda 1,3, \\ Yosef Gebrehawaryat Kidane ${ }^{1}$, Dejene Mengistu ${ }^{1}{ }^{1 D}$, Afewerki Yohannes Kiros ${ }^{3}$, Jemal Nurhisen Mohammed ${ }^{5}$, \\ Mekonen Assefa ${ }^{6}$, Tesfaye Woldesemayate ${ }^{4}$ and Francesco Caracciolo ${ }^{1,7}$ (D)
}

check for

updates

Citation: Gotor, E.; Usman, M.A.; Occelli, M.; Fantahun, B.; Fadda, C.; Kidane, Y.G.; Mengistu, D.; Kiros, A.Y.; Mohammed, J.N.; Assefa, M.; et al. Wheat Varietal Diversification Increases Ethiopian Smallholders' Food Security: Evidence from a Participatory Development Initiative. Sustainability 2021, 13, 1029.

https://doi.org/10.3390/su13031029

Academic Editor: Filippo Giarratana Received: 10 December 2020

Accepted: 13 January 2021

Published: 20 January 2021

Publisher's Note: MDPI stays neutral with regard to jurisdictional claims in published maps and institutional affiliations.

Copyright: (c) 2021 by the authors. Licensee MDPI, Basel, Switzerland. This article is an open access article distributed under the terms and conditions of the Creative Commons Attribution (CC BY) license (https:/ / creativecommons.org/licenses/by/ $4.0 /)$.
1 Bioversity International, 00100 Rome, Italy; c.fadda@cgiar.org (C.F.); y.gebrehawaryat@cgiar.org (Y.G.K.); d.mengistu@cgiar.org (D.M.); f.caracciolo@cgiar.org (F.C.)

2 Center for Development Research (ZEF), Bonn University, Genscherallee 3, 53113 Bonn, Germany; mausman25@gmail.com

3 Scuola Superiore Sant'Anna, 34, 56025 Pontedera, Italy; m.occelli@santannapisa.it (M.O.); basazenfantahun.lakew@santannapisa.it (B.F.); afewerkiyohannes.kiros@santannapisa.it (A.Y.K.)

4 Ethiopian Biodiversity Institute (EBI), Addis Ababa 1000, Ethiopia; mikiyabtes@gmail.com

5 Department of Dryland Crop and Horticultural Sciences, College of Dryland Agriculture and Natural Resources, Mekelle University, P.O. Box 231, Mekelle, Tigray, Ethiopia; Jemdej2013@gmail.com

6 Sirinka Agricultural Research Center, P.O. Box 74, North Wollo, Woldia, Ethiopia; sabekmeko@gmail.com

7 Economics and Policy Group, Federico II, Department Agricultural Sciences, University of Naples Federico II, Via Claudio, 21, 80125 Naples, Italy

* Correspondence: e.gotor@cgiar.org

Abstract: This study assesses the impact of a participatory development program called Seeds For Needs, carried out in Ethiopia to support smallholders in addressing climate change and its consequences through the introduction, selection, use, and management of suitable crop varieties. More specifically, it analyzes the program's role of boosting durum wheat varietal diversification and agrobiodiversity to support higher crop productivity and strengthen smallholder food security. The study is based on a survey of 1008 households across three major wheat-growing regional states: Amhara, Oromia, and Tigray. A doubly robust estimator was employed to properly estimate the impact of Seeds For Needs interventions. The results show that program activities have significantly enhanced wheat crop productivity and smallholders' food security by increasing wheat varietal diversification. This paper provides further empirical evidence for the effective role that varietal diversity can play in improving food security in marginal environments, and also provides clear indications for development agencies regarding the importance of improving smallholders' access to crop genetic resources.

Keywords: on-farm diversity; adoption; durum wheat; crowdsourcing

\section{Introduction}

While agricultural production is systematically subject to uncertainty due to variability in temperature and precipitation [1], climate change is expected to amplify these adverse impacts [2]. More specifically, the Intergovernmental Panel on Climate Change (IPCC) argues that climate change will cause a reduction in agricultural production, especially in sub-Saharan Africa, unless proper adaptation strategies are in place [3,4]. Indeed, rain-fed subsistence farmers, with limited capacity to invest in coping and mitigation strategies [5], will be among the most deeply affected [6-8]. Therefore, it is crucial to support these farmers in reducing their vulnerability to shocks, strengthening their livelihoods and sustainably ensuring their food security. Part of the solution lies in improving on-farm production diversity. 
Predictions of climate change's impacts are promoting agricultural interventions and strategies in many developing countries to strengthen smallholders' capacity to cope with a changing environment that threatens agricultural production and livelihood opportunities. Several studies, for example, Refs. [9-12], conducted in marginal production areas highlight the importance of increasing diversity in farming systems to moderate the negative impacts of climate change and climate variability. Diversifying farming systems and increasing linked agrobiodiversity may positively affect smallholders' livelihoods in various ways $[13,14]$. This includes crop diversification, which can reduce the production uncertainty tied to climate variability and unpredictable weather conditions $[5,11,15-19]$.

For subsistence farmers, production uncertainty can result in food insecurity and livelihood loss. The increased availability of a range of genetically diverse crop varieties allows farmers to select suitable cultivars that respond to new microclimate conditions [20] and improve farmers' capabilities to effectively control pests and diseases [21-25]. All of these have direct implications for crop productivity and smallholders' food security and livelihoods [14,19,26-28]. The impact of diversification on agricultural income is, however, context-specific and mixed $[19,29]$.

Climate change is negatively impacting agriculture in parts of sub-Saharan Africa more deeply than elsewhere, including parts of Ethiopia. According to FAOSTAT, during 2018, $85 \%$ of the Ethiopian population of approximately 109 million people were engaged in agriculture [30], and eight out of ten Ethiopian farmers were smallholders, supplying more than $90 \%$ of agricultural production [31]. Around $15 \%$ were food-insecure. Given their lowinput farming systems and low adaptive capacity in the face of environmental variability, most smallholders are increasingly threatened by climate change [32]. These farmers often conduct subsistence agriculture based on landraces and improved varieties selected for their adaptive traits to local conditions [33]. Ethiopia is one of the global hotspots for the genetic diversity of many crops, including durum wheat [34]. Durum wheat (Triticum durum Desf.) represents one of the main cereal crops grown, and it accounts for $20 \%$ of the country's total wheat production. Smallholders have a majority share in its production $[35,36]$.

Though farmers might mix wheat varieties in their fields, they normally lack the resources and information needed to access a diversified set of better-performing varieties. Additionally, they are often excluded from formal scientific debates, which results in a poor integration of their local and traditional knowledge into breeding programs.

To facilitate the adoption and conservation of well-performing local varieties by smallholders, a participatory development program, namely Seeds for Needs (S4N) [37], was launched by CGIAR in partnership with the Ethiopian Biodiversity Institute in 2011. The aim of the initiative was twofold: (i) to improve the livelihoods and food security of smallholders by providing them access to a range of genetically diverse and well-adapted superior varieties of key staple crops, such as wheat and barley, and (ii) to support the communities in coping with climate change consequences and related shocks. The S4N program has been implemented in Amhara and Tigray regions since 2013, in collaboration with the Sirinka Agricultural research center (SARC) and Mekelle University (MU), respectively, to increase the number of beneficiary smallholder farmers by providing climate change-resilient varieties. Meket woreda in the Amhara region and Degua Tembein in the Tigray region were the focus sites for the S4N program from 2014 to 2016. Altogether, more than 400 smallholder farmers participated at the beginning, and ultimately this increased to 1350 during the second and third seasons of varietal evaluation and selection. This helped to identify superior durum wheat varieties for increasing the varietal diversity and productivity of the target areas. The $\mathrm{S} 4 \mathrm{~N}$ program aimed to expand the seed portfolio of individual participant farmers by three varieties. At the beginning of the intervention, each farmer received $10 \mathrm{~g}$ of three different varieties that could each cover a $0.4 \mathrm{~m}^{2}$ area. Ultimately, through seed multiplication, the coverage increased to 1 ha in the third season per farmer per variety. 
At the heart of the initiative is the analysis and characterization of crop and varietal diversity and associated adaptive capacity, given specific ecoregions and changing climatic conditions. Rather than focusing on formal breeding or introducing new varieties at the beginning of the intervention, $\mathrm{S} 4 \mathrm{~N}$ harnessed an opportunity to achieve quick wins in a cost-efficient way by using and reintroducing a range of diverse, superior landraces readily available in local genebanks [38-40]. This was then followed by an extensive participatory breeding program [41]. S4N was implemented by adopting participatory approaches (e.g., participatory varietal selection (PVS), crowdsourcing, on-farm trials, and communitybased approaches for agrobiodiversity management) that involved farmers both in the understanding and in the conservation of this diversity. Mancini et al. [41] and Van Etten et al. [42] highlight the importance of participatory approaches, whereby farmers are "put at the center of research activities and are involved as citizen scientists", in selecting the traits that accommodate local constraints and conditions, and meet local needs.

Interventions belonging to the S4N initiative are generally complex, and articulated, to various extents [37], on multiple levels-from local to national-and across scientific domains (e.g., the characterization and selection of genetic resources, crop improvement, cropping systems, nutrition). Farmers are exposed to a range of crop varieties potentially suitable for the agroecological zone(s) in which they operate, and offer their fields for on-farm experimental trials of these varieties $[16,41,43,44]$. Participatory varietal selection (PVS) and the establishment of community seedbanks are promoted as activities that are part of an integrated conservation strategy that combines on-farm, in-situ and ex-situ approaches, and promotes networks of national and local genebanks and seedbanks to enhance the availability of high-quality seeds of the preferred varieties [43]. This approach builds farmers' capacities for making better-informed decisions regarding varietal choice and performance. It also strengthens social cohesion and fosters new networks among farmers, which in turn tends to increase the adoption and dissemination of the new varieties $[45,46]$.

The current study assesses the impact of smallholders' participation in Ethiopia's S4N program. It firstly assesses the impact of the S4N program [37] on wheat varietal diversification among smallholders in three major Ethiopian wheat-growing regional states: Amhara, Oromia, and Tigray. Secondly, it assesses the impact of the interventions, and therefore the role(s) of boosting varietal diversification and agrobiodiversity in crop productivity and food security. Figure 1 presents the associated theory of change, and summarizes the actors involved in the S4N program alongside the different activities that were carried out. The empirical analysis focuses on identifying the causal relations between program participation and the outcomes and impacts highlighted in the figure.

While previous research has mainly assessed the beneficial effects of crop diversification (namely inter-specific diversity) [47-49], studies focusing on smallholders' decisions to increase varietal diversification (namely intra-specific diversity) and analyzing its effects on household well-being remain scarce. Some studies have investigated the impact of adopting improved or hybrid crop varieties on farmers' livelihood outcomes [35,50-52]. Shiferaw, Kassie, Jaleta and Yirga [35], for instance, reported that farmers who adopted improved wheat varieties had significantly improved food security compared to nonadopters. Recently, Teferi et al. [53] demonstrated that Ethiopian farmers are willing to pay more for varieties with characteristics relevant to their major biotic and abiotic climate-related challenges. It is widely demonstrated that an appropriate selection of crop varieties may effectively help vulnerable smallholders to deal with variable and extreme weather conditions. However, smallholders generally lack the necessary knowledge or resources to properly identify and assess which wheat variety traits (e.g., pest or disease resistance, input requirements, yield potential, and drought tolerance) best suit their local agro-ecological conditions. Specific development interventions are often required to close this gap. Such programs must include appropriate and multidimensional interventions, because smallholders operate in complex systems characterized by continuous interactions between economic, environmental and social forces [13]. 
This paper contributes by providing further empirical evidence of the role(s) played by varietal diversity in improving food security in marginal environments, considering the real farming conditions and the actual system of incentives that these smallholders are facing. Indeed, to the best of our knowledge, the only previous empirical study analyzing the influence of on-farm varietal diversity in improving a household's wellbeing was carried out by Di Falco et al. [54].

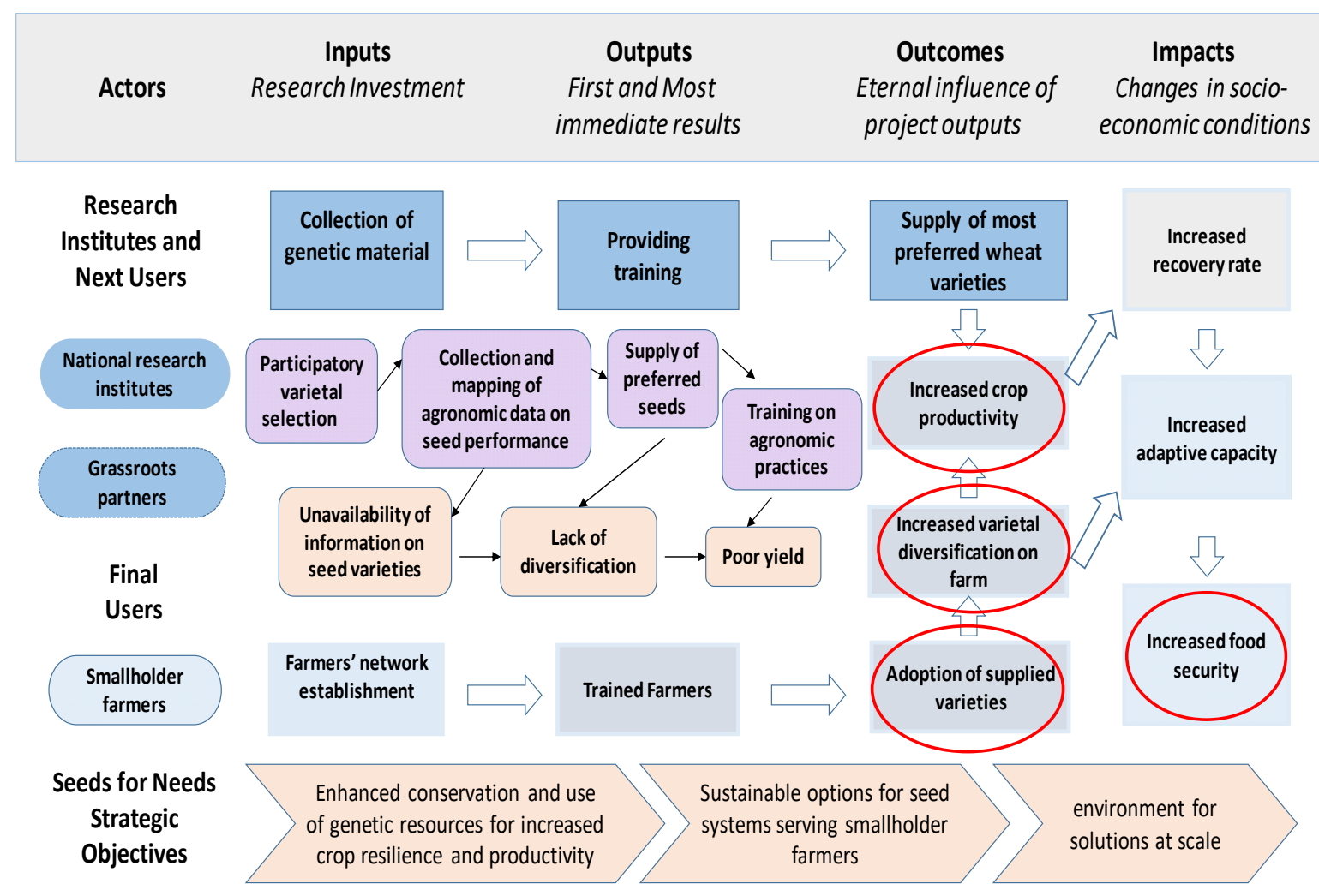

Figure 1. Flow of activities and events with consequential outcomes and impacts (i.e., theory of change) hypothesized by the Seeds for Needs (S4N) initiative.

\section{Materials and Methods}

The field work was conducted in three areas of Ethiopia: North-Wollo in the Amhara region; central-in the Tigray region; and the district of Chefe Donsa in Oromia. The first two sites are situated in a highland ecosystem, in a range between $2430 \mathrm{~m}$ and $3240 \mathrm{~m}$ above sea level (masl). Respondents in Amhara live between 2443 and 3240 masl; the selected study area in Tigray spans an altitude of 2430 to 2679 masl. The sites in Oromia are lower in altitude. The regions are subject to sub-tropical climates, with one main rainy season (meher) in summer, between June and August, and a second shorter period of occasional rainfalls (belg) from February to May. The study sites are marginal areas and are representative of low-intensive cereal cultivation regions, especially focused on harvesting wheat, barley and teff (45). Crop and livestock production remain the two main livelihoods, characterized by low-input soil tillage technology and absence of irrigation. Oxen ploughing is ubiquitous, and cropping systems are mainly rainfed. Furthermore, animal feeding is based on crop residues.

\subsection{Data Collection}

The $\mathrm{S} 4 \mathrm{~N}$ program was implemented in two sequential steps. The first step involved the characterization of 373 durum wheat landraces together with 27 improved durum wheat varieties in Amhara and Tigray regions during 2012 and 2013 cropping seasons, using a $20 \times 20$ partial lattice trial plot design, replicated twice. Participatory varietal 
selections (PVSs) have been carried out involving 15 women and 15 men farmers, randomly selected, who identified the traits of preference for their wheat variety selection and picked the top three using pair-wise ranking at each location during the 2013 cropping season. Then, each trial plot was evaluated based on previously identified traits-for earliness, spike quality, tillering capacity, and finally the overall performance of the varieties. Based on the average performance for these traits, the 400 tested genotypes were ranked and the top 32 were progressed to the second step. The second step involved the further testing of selected durum wheat varieties in farmers' fields under their own management, using a crowdsourcing approach. From 2013 to 2016, 1350 farmers in more than 66 villages in the Amhara, Oromia and Tigray regions were randomly selected and then trained on varietal evaluation and selection and provided with three varieties to grow in their own fields and evaluate under their own management. Each participant farmer evaluated and ranked the three varieties based on their own traits of preference, and the detailed reasonings for the ranks were collected from farmers as feedback by the research team in each region. Participant farmers voluntarily offered the selected varieties and associated knowledge to other farmers during the subsequent years.

The empirical assessment undertaken in this study uses primary household survey data based on a sample of 1008 households in Ethiopia. The household survey was conducted between February and March 2019 in three regional states of Ethiopia where the $\mathrm{S} 4 \mathrm{~N}$ initiative was previously implemented: Amhara, Oromia, and Tigray. A total of 66 villages were randomly selected: 18 villages each from Amhara and Tigray, of which 12 participated in $\mathrm{S} 4 \mathrm{~N}$ activities, and 6 were randomly selected among non-participating villages and 30 villages from Oromia region. The selected communities captured variability in a wide range of agro-climatic conditions, agricultural diversity, and socio-economic contexts, among other factors. Trained enumerators working closely with the communities and local partners collected the data from the household heads, as representatives of the prevailing circumstances at the household level. While the original sample size was set to 1008 , due to incomplete information in some key variables of the questionnaire, data from 957 households were ultimately used for the empirical analysis. Table 1 summarizes the distribution of the sampled households by region and participation status.

The survey collected a wide range of information about households' activities and their demographic and economic characteristics that could potentially influence agricultural practices, including the adoption or use of crop diversity. Demographic and socioeconomic variables, such as distance to market, a household's perception of their own food security status in the last 12 months before the survey, the age, gender, and education level of the household head, family size, crop and variety choices, farm production, off-farm activities, asset ownership, social networks, and intra-household decision making, as well as an assessment of production conditions in the previous harvest season, among other indicators, were included in the survey.

Table 1. Sampled villages and households.

\begin{tabular}{ccccc}
\hline Study Regions & \# Villages & Participants & $\begin{array}{c}\text { Non- } \\
\text { Participants }\end{array}$ & Total Sample \\
\hline Amhara & 18 & 144 & 144 & 288 \\
Tigray & 18 & 144 & 144 & 288 \\
Oromia & 30 & 282 & 150 & 432 \\
Total & 66 & 570 & 438 & 1008 \\
\hline
\end{tabular}

Source: Authors' own survey.

\subsection{Analyzed Outcomes}

The impact of the $\mathrm{S} 4 \mathrm{~N}$ initiatives was estimated for several outcomes. To measure agrobiodiversity at the household level, we used two indicators that have often been used in ecological and biodiversity studies and are cited in the literature. Firstly, we used the Margalef variety richness index, which accounts for the number of crop varieties, 
but considering likewise the area cultivated with different crop species on the farm $[17,18]$. This can be computed as:

$$
\text { Margalef species richness index }=\frac{(s-1)}{\ln A}
$$

where $s$ is the number of varieties grown, and $A$ is the total land size, closely following Sibhatu, Krishna and Qaim [55].

Moreover, in order to account also for the evenness (distribution of area cultivated) of the diversity, the Simpson's Diversity Index [56] was used, which includes also the richness concept. The index is defined as:

$$
\text { Simpson's diversity index }(S I)=1-\sum_{j=1}^{J} P_{j}^{2} \text {, with } P_{j}=a_{i j} / A_{i}
$$

where $P_{j}$ is the share of the $j$-th variety in the total area cultivated by the $i$-th household, and $a_{i j}$ is the area cultivated for the $j$-th variety by the $i$-th household, with $A_{i}$ as the total area cultivated under all wheat varieties. The value of the SI ranges between 0 and 1 , with the SI increasing as a household's wheat varietal diversity increases.

Both the Margalef species richness index and the Simpson's diversity can be similarly interpreted: a higher value of the index indicates a higher degree of varietal diversity. The use of both indexes can be considered as a sensitivity check as to whether the initial findings hold under different farm-diversity measurements.

Yield change, or crop productivity, is one of the channels through which varietal diversity might impact household livelihoods and food security. Yield change is measured as:

$$
\Delta Y=\frac{Y_{t}-Y_{t-5}}{Y_{t-5}}
$$

where $Y_{t}$ represents the latest total wheat production in kilograms, while $Y_{t-5}$ represents the stated average production obtained five years before the survey.

Concerning food security, two indicators are used. The first indicator simply relies on the following survey question, asking households: "Is there a time of the year when there is less food compared to other times?" An indicator was built based on the household response, assuming a value of 1 if the household answers "yes" and 0 otherwise. Moreover, based on this answer, households were asked to report the months in which food availability was inadequate. Thus, the number of months in the previous year in which a household experienced inadequate food provision was counted (IHFP).

To conclude, Table 2 reports the description of the variables used in the empirical analysis, and the summary statistics by region. The three sites show some endemic differences, despite all three being representative of marginal rural ecosystems. For example, the study area of Tigray suffers a higher level of food insecurity both in terms of absolute perception and in terms of months of inadequate food availability. The study site in Oromia scores higher on the wealth index, but Amhara farmers report higher yield increases for the previous five years. There could be different reasons for registering higher yield increase in Oromia. The major reason could be the adoption and production of identified wheat varieties through the $\mathrm{S} 4 \mathrm{~N}$ project. Secondly, the knowledge gained by farmers due to their active participation during the implementation of $\mathrm{S} 4 \mathrm{~N}$ project might have contributed to the increase. Membership in informal institutions, such as the above-reported idir, is a milestone in all three communities - even though this specific institution is less diffuse in Tigray. 
Table 2. Description of the variables and summary statistics by region.

\begin{tabular}{|c|c|c|c|c|c|}
\hline Variable & Description/Measurement & Total & Tigray & Amhara & Oromia \\
\hline $\begin{array}{l}\text { Simpson diversity } \\
\text { index-wheat }\end{array}$ & $\begin{array}{l}\text { First measure of wheat variety diversity at } \\
\text { the household level }\end{array}$ & $\begin{array}{c}0.52 \\
{[0.40]}\end{array}$ & $\begin{array}{c}0.61 \\
{[0.41]}\end{array}$ & $\begin{array}{c}0.37 \\
{[0.27]}\end{array}$ & $\begin{array}{c}0.58 \\
{[0.44]}\end{array}$ \\
\hline Wheat variety count & $\begin{array}{l}\text { Second measure of wheat variety diversity at } \\
\text { the household level }\end{array}$ & $\begin{array}{c}1.55 \\
{[0.81]}\end{array}$ & $\begin{array}{c}1.38 \\
{[0.73]}\end{array}$ & $\begin{array}{c}1.68 \\
{[0.84]}\end{array}$ & $\begin{array}{c}1.57 \\
{[0.81]}\end{array}$ \\
\hline Margalef index-wheat & $\begin{array}{l}\text { Third measure of wheat variety diversity at } \\
\text { the household level }\end{array}$ & $\begin{array}{c}0.06 \\
{[0.08]}\end{array}$ & $\begin{array}{c}0.05 \\
{[0.07]}\end{array}$ & $\begin{array}{c}0.08 \\
{[0.09]}\end{array}$ & $\begin{array}{c}0.06 \\
{[0.07]}\end{array}$ \\
\hline Food insecure-Yes = 1 & $\begin{array}{l}\text { Household's food security status in the last } \\
12 \text { months before the survey }\end{array}$ & $\begin{array}{c}0.53 \\
{[0.50]}\end{array}$ & $\begin{array}{c}0.83 \\
{[0.38]}\end{array}$ & $\begin{array}{c}0.44 \\
{[0.50]}\end{array}$ & $\begin{array}{c}0.38 \\
{[0.49]}\end{array}$ \\
\hline Months of IHFP & $\begin{array}{l}\text { The number of months in which household's } \\
\text { food availability was inadequate in the last } \\
12 \text { months before the survey }\end{array}$ & $\begin{array}{c}1.39 \\
{[1.56]}\end{array}$ & $\begin{array}{c}2.57 \\
{[1.57]}\end{array}$ & $\begin{array}{c}1.19 \\
{[1.58]}\end{array}$ & $\begin{array}{c}0.74 \\
{[0.99]}\end{array}$ \\
\hline Yield change & $\begin{array}{l}\text { The change in wheat yield in } 2018 \text { compared } \\
\text { to five years before }\end{array}$ & $\begin{array}{c}0.43 \\
{[2.47]}\end{array}$ & $\begin{array}{c}0.21 \\
{[1.29]}\end{array}$ & $\begin{array}{c}0.76 \\
{[4.10]}\end{array}$ & $\begin{array}{c}0.36 \\
{[1.49]}\end{array}$ \\
\hline Male headed HH-Yes = 1 & Male headed households_-Yes = 1 & $\begin{array}{c}0.87 \\
{[0.34]}\end{array}$ & $\begin{array}{c}0.86 \\
{[0.34]}\end{array}$ & $\begin{array}{c}0.89 \\
{[0.32]}\end{array}$ & $\begin{array}{c}0.85 \\
{[0.36]}\end{array}$ \\
\hline $\mathrm{HH}$ head age & Household's head age in years & $\begin{array}{c}48.71 \\
{[13.57]}\end{array}$ & $\begin{array}{c}51.00 \\
{[12.83]}\end{array}$ & $\begin{array}{c}50.46 \\
{[12.52]}\end{array}$ & $\begin{array}{c}45.91 \\
{[14.28]}\end{array}$ \\
\hline $\begin{array}{l}\text { HH head education level [0-3 } \\
\text { category] }\end{array}$ & $\begin{array}{l}\text { Level of education based on years of } \\
\text { schooling }\end{array}$ & $\begin{array}{c}0.69 \\
{[0.88]}\end{array}$ & $\begin{array}{c}0.72 \\
{[0.84]}\end{array}$ & $\begin{array}{c}0.58 \\
{[0.82]}\end{array}$ & $\begin{array}{c}0.75 \\
{[0.94]}\end{array}$ \\
\hline Household size & Number of household members & $\begin{array}{c}5.50 \\
{[1.80]}\end{array}$ & $\begin{array}{c}5.57 \\
{[1.82]}\end{array}$ & $\begin{array}{c}5.33 \\
{[1.61]}\end{array}$ & $\begin{array}{c}5.57 \\
{[1.91]}\end{array}$ \\
\hline $\begin{array}{l}\text { Idir group number [0-3 } \\
\text { category] }\end{array}$ & $\begin{array}{l}\text { The number of people in the group } \\
\text { membership }\end{array}$ & $\begin{array}{l}1.96 \\
{[1.06]}\end{array}$ & $\begin{array}{c}0.71 \\
{[0.67]}\end{array}$ & $\begin{array}{c}2.05 \\
{[0.79]}\end{array}$ & $\begin{array}{c}2.74 \\
{[0.52]}\end{array}$ \\
\hline $\begin{array}{l}\text { Living in the kebele [1-3 } \\
\text { category] }\end{array}$ & $\begin{array}{l}\text { The number of years the household has been } \\
\text { living in the village }\end{array}$ & $\begin{array}{c}2.24 \\
{[0.56]}\end{array}$ & $\begin{array}{c}2.28 \\
{[0.57]}\end{array}$ & $\begin{array}{c}2.11 \\
{[0.61]}\end{array}$ & $\begin{array}{c}2.30 \\
{[0.50]}\end{array}$ \\
\hline Farm size & Farm size in hectares & $\begin{array}{c}1.37 \\
{[0.98]}\end{array}$ & $\begin{array}{c}0.81 \\
{[0.46]}\end{array}$ & $\begin{array}{c}0.97 \\
{[0.56]}\end{array}$ & $\begin{array}{c}2.09 \\
{[1.05]}\end{array}$ \\
\hline Number of plots & $\begin{array}{l}\text { Number of plots cultivated in the last } \\
\text { production season }\end{array}$ & $\begin{array}{c}3.90 \\
{[2.12]}\end{array}$ & $\begin{array}{c}3.16 \\
{[1.60]}\end{array}$ & $\begin{array}{c}3.08 \\
{[1.34]}\end{array}$ & $\begin{array}{c}5.05 \\
{[2.40]}\end{array}$ \\
\hline Soil fertility & $\begin{array}{l}\text { Degree of soil fertility averaged over plots ( } 1 \\
=\text { poor, } 2=\text { medium, } 3=\text { fertile) }\end{array}$ & $\begin{array}{c}2.15 \\
{[0.49]}\end{array}$ & $\begin{array}{c}2.07 \\
{[0.55]}\end{array}$ & $\begin{array}{c}2.02 \\
{[0.44]}\end{array}$ & $\begin{array}{c}2.31 \\
{[0.43]}\end{array}$ \\
\hline Access to information & $\begin{array}{l}1=\text { if a household owns at least a mobile } \\
\text { phone/radio/ television, } 0 \text { otherwise }\end{array}$ & $\begin{array}{c}0.81 \\
{[0.40]}\end{array}$ & $\begin{array}{c}0.85 \\
{[0.36]}\end{array}$ & $\begin{array}{c}0.61 \\
{[0.49]}\end{array}$ & $\begin{array}{c}0.92 \\
{[0.27]}\end{array}$ \\
\hline Distance to market in hours & $\begin{array}{l}\text { Distance to the nearest market in walking } \\
\text { hours }\end{array}$ & $\begin{array}{c}0.86 \\
{[0.54]}\end{array}$ & $\begin{array}{c}0.98 \\
{[0.46]}\end{array}$ & $\begin{array}{c}0.97 \\
{[0.65]}\end{array}$ & $\begin{array}{c}0.70 \\
{[0.46]}\end{array}$ \\
\hline Off-farm income & $\begin{array}{l}1=\text { if a household member engaged in any } \\
\text { off-farm activities in the previous } 12 \text { months } \\
\text { survey, } 0 \text { otherwise }\end{array}$ & $\begin{array}{c}0.58 \\
{[0.49]}\end{array}$ & $\begin{array}{c}0.80 \\
{[0.40]}\end{array}$ & $\begin{array}{c}0.67 \\
{[0.47]}\end{array}$ & $\begin{array}{c}0.36 \\
{[0.48]}\end{array}$ \\
\hline Wealth index [0-100] & $\begin{array}{l}\text { Includes assets, livestock units, and } \\
\text { structures }\end{array}$ & $\begin{array}{c}46.12 \\
{[20.22]}\end{array}$ & $\begin{array}{c}34.75 \\
{[11.71]}\end{array}$ & $\begin{array}{c}34.49 \\
{[13.98]}\end{array}$ & $\begin{array}{c}62.07 \\
{[17.52]}\end{array}$ \\
\hline Observations & & 957 & 271 & 285 & 401 \\
\hline
\end{tabular}

Note: Standard deviation in block brackets.

\subsection{Empirical Strategy}

One of the primary challenges when evaluating the impact of an initiative based on observational data is the estimation bias, due to the non-random assignment of the program, and the self-selection of participants into the program. The initial participation in the S4N initiative was as follows: in Tigray and Amhara, 12 villages were selected using Google Earth to represent the entire wheat-growing area landscape, covering an area 
of about $450 \mathrm{~km}^{2}$. Within each village, wheat-growing farmers were randomly selected using the list of households obtained from the kebele (the smallest administrative unit of Ethiopia, similar to a ward, a neighborhood or a localized and delimited group of people). Each household was assigned with a number and the target households selected by randomizing those numbers. To avoid any source of non-randomness of program participation, we employed the doubly robust estimator [57] to quantify the benefits arising from the program, and specifically, to determine if the observable differences between households participating in the program compared to those not involved can be effectively ascribed to the $\mathrm{S} 4 \mathrm{~N}$ initiative.

The estimator models both the program's outcome and its participation in order to account for selection bias or non-random households' participation. The main advantage of this approach is its double-robust property, which allows the effect of participating in a program to be consistently estimated, provided that either the outcome or the participation model is correctly specified [58,59]. Analytically,

$$
D R=\frac{1}{N} \sum_{i=1}^{N} \frac{\mathrm{W}_{\mathrm{i}} \mathrm{Y}_{\mathrm{i}}-\left(\mathrm{W}_{\mathrm{i}}-p\left(\hat{\mathrm{x}}_{\mathrm{i}}\right)\right) \hat{Y}_{i 1}}{p\left(\hat{\mathrm{x}}_{\mathrm{i}}\right)}-\frac{1}{N} \sum_{i=1}^{N} \frac{\left(1-\mathrm{W}_{\mathrm{i}}\right) \mathrm{Y}_{\mathrm{i}}+\left(\mathrm{W}_{\mathrm{i}}-p\left(\hat{\mathrm{x}}_{\mathrm{i}}\right)\right) \hat{Y}_{i 0}}{1-p\left(\hat{\mathrm{x}}_{\mathrm{i}}\right)}
$$

where $Y_{i, 1}$ is the observed outcome for the $i$-th household participating in the initiative, $Y_{i, 0}$ is the outcome for the non-participant household, $x_{i}$ represents a vector of the household's characteristics, while $p\left(\mathrm{x}_{\mathrm{i}}\right)$ is the conditional probability of participating, with the propensity score $\left(\mathrm{W}_{\mathrm{i}}=1\right)$, or non-participating $\left(\mathrm{W}_{\mathrm{i}}=0\right)$.

Firstly, the probability of participating in the $\mathrm{S} 4 \mathrm{~N}$ project $\left(p\left(\mathrm{x}_{\mathrm{i}}\right)\right)$ was estimated using a probit model. The selection of the explanatory variables is based on economic theory and the literature on the adoption and impact of agricultural technologies $[35,60]$. The variables include socioeconomic and demographic characteristics, such as age, gender, and years of education of the household head, household size, farm size, number of plots, and assets, as well as off-farm activities, access to market and information, and social capital-related variables, among others. Several of these variables are important determinants for the adoption of agricultural technologies. We also include regional dummies to account for regional heterogeneity. Table 2 presents a detailed description of the variables included in the models. Secondly, regression models of the outcome are fitted to obtain the expected outcomes for participants $\left(\hat{Y}_{i 1}\right)$ and non-participants $\left(\hat{Y}_{i 0}\right)$ of the $S 4 \mathrm{~N}$ project. Finally, equation 4 is computed, providing the estimates of the effects of participating in the $54 \mathrm{~N}$ activities. Households were invited to participate in four different activities of the S4N initiative in 2013, as follows: (a) training for the evaluation of new wheat varieties, (b) training activities about community seedbank management, (c) implementing good agronomic practices, and (d) crowdsourcing. In this study, participant households are those households that joined in at least one of the four activities (i.e., $\mathrm{W}_{\mathrm{i}}$ is equal to 1 if a household is involved in at least one activity; 0 otherwise).

\section{Results}

\subsection{Who Are the Participating Households?}

As previously discussed, the $\mathrm{S} 4 \mathrm{~N}$ program requested four different types of activities for participant households. Figure 2 presents the proportion of households participating in each S4N activity. As the figure shows, the majority (58\%) of sampled households participated in at least one activity, while $7 \%$ of the households were involved in all four training types. About $19 \%$ of the sampled households participated in only one type, $18 \%$ participated in at least two, and $14 \%$ participated in at least three. The survey also revealed that $44 \%$ of the sampled households reported receiving training for the evaluation of new wheat varieties, but only $24 \%$ of households reported participating in crowdsourcing activities. 


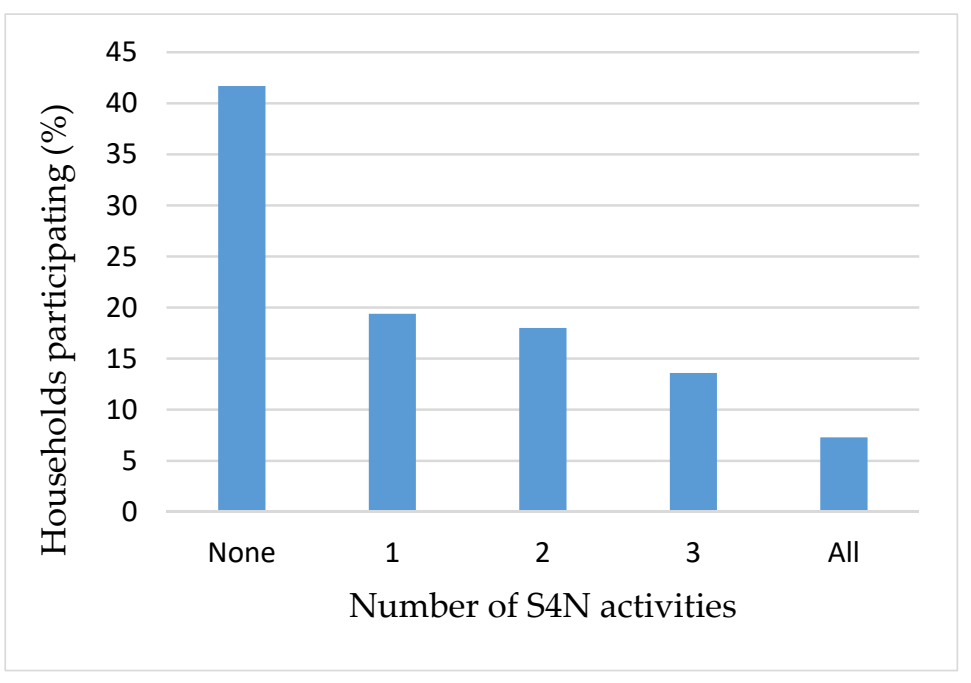

Figure 2. Proportions of household participation in the S4N interventions.

Table 3 displays the parameter estimates of the probit model, which is used to analyze the households' participation in the $\mathrm{S} 4 \mathrm{~N}$ initiative. The estimates are also needed when calculating the probability of participating in the $\mathrm{S} 4 \mathrm{~N}$ project, an essential component of the DR estimator that will use this information to control for any source of sample selection bias.

The survey results reveal the factors that influence a household's choice regarding participating in the $\mathrm{S} 4 \mathrm{~N}$ program [61]. The results suggest that the age of the household head, number of plots, perceived degree of soil fertility, and wealth level are among the key determining factors that influence the decision to participate in the $S 4 \mathrm{~N}$ project. Meanwhile, the level of education and gender of the household head does not significantly affect participation, suggesting that both male- and female-headed households are equally likely to participate in the program. The insignificance of education level in participation might be associated with the overall education level of the community. Most farmers are uneducated. In the rural setting of Ethiopia, farmers participate in agricultural research with the help of local development agents and local institutions. As such, the few educated and the majority uneducated farmers have an equal chance of participation. On the other hand, educated farmers participate in off-farm activities, and their participation in agricultural research is minimal. This is despite female-headed households being generally more likely to be vulnerable due to limited access to productive resources, assets, and labor constraints, among other reasons [62]. Households living longer in the village are more likely to participate in the activities. This could be because longer-established households may have stronger social networks, with information reaching them quickly. The number of plots also influences the household's decision of whether or not to participate in the initiative; having more plots allows a given farmer to experiment with new varieties and agronomic practices. The soil fertility of the plot is also a significant predictor of household participation decisions; that is, households with more fertile soils are likelier program participants. The results further suggest that the wealthiest households are more likely to participate in the project than the poorest ones, because of the availability of owned plots that allows them to experiment with new varieties and agronomic practices. 
Table 3. Parameter estimates for factors influencing S4N participation-Probit estimates.

\begin{tabular}{|c|c|c|}
\hline & Coefficients & $p$-Values \\
\hline Male headed $\mathrm{HH}-$ Yes $=1$ & 0.190 & 0.171 \\
\hline HH head age & 0.007 & 0.062 \\
\hline HH head education level (base = No education) & ref. & \\
\hline Less than 5 years of education & -0.106 & 0.369 \\
\hline Between 5 and 10 years of education & -0.153 & 0.234 \\
\hline More than 10 years of education & 0.116 & 0.675 \\
\hline Household size & -0.019 & 0.470 \\
\hline Idir group number (base = None) & ref. & \\
\hline$<50$ members & 0.191 & 0.255 \\
\hline 51-100 members & 0.264 & 0.217 \\
\hline Greater than 100 members & 0.201 & 0.359 \\
\hline Years living in the Kebele/village (base $\leq 10$ years) & ref. & \\
\hline Less than 50 years & 0.306 & 0.088 \\
\hline More than 50 Years & 0.500 & 0.010 \\
\hline Farm size in ha & -0.073 & 0.313 \\
\hline Number of plots & 0.068 & 0.033 \\
\hline Soil fertility & 0.215 & 0.021 \\
\hline Access to information-Yes $=1$ & 0.154 & 0.240 \\
\hline Distance to market in hours & 0.113 & 0.177 \\
\hline Off farm income-Yes $=1$ & 0.123 & 0.190 \\
\hline Wealth Index [0-100] & 0.008 & 0.008 \\
\hline Survey region (base $=$ Tigray) & ref. & \\
\hline Amhara & -0.277 & 0.094 \\
\hline Oromia & -0.403 & 0.054 \\
\hline Constant & -1.755 & 0.000 \\
\hline
\end{tabular}

Statistically significant coefficients $(p<0.05)$ are reported in bold.

\subsection{The Impact of Participation on Wheat Varietal Diversification, Productivity and Food Security}

This section summarizes the key findings of the study based on doubly robust specifications. The impacts of the S4N interventions regarding on-farm wheat varietal diversification, wheat productivity, and food security are summarized in Table 4. It estimates the average treatment effect on the treated farmers (ATT), which is relevant in the context of an impact assessment whereby the impact of the program is generally computed via its consequences on participants. Results suggest that the effects of the $\mathrm{S} 4 \mathrm{~N}$ initiative are positive and statistically significant for both the agrobiodiversity measures and the food security indicator variables. Concerning the agrobiodiversity measures, the Simpson diversity index for beneficiary households is, on average, $11.8 \%$ higher than the non-beneficiary households. Yield change $(29 \%)$ is also positive and significant for beneficiary households compared to the non-beneficiary ones.

Table 4. Summary results of the DR estimator.

\begin{tabular}{cccccc}
\hline & Non-Beneficiary & Beneficiary & DR Estimate & $p$-Value & ATT (\% Effect) \\
\hline Simpson index-wheat & 0.467 & 0.563 & 0.055 & 0.03 & $11.78^{* *}$ \\
Margalef species richness index & 0.055 & 0.068 & 0.010 & 0.07 & $18.18^{*}$ \\
Food insecurity-Yes = & 0.559 & 0.502 & -0.072 & 0.03 & $-12.20^{* *}$ \\
Months of inadequate household & 1.494 & 1.323 & -0.153 & 0.10 & $-10.24^{*}$ \\
food provision (IHFP) & 0.292 & 0.533 & 0.289 & 0.07 & $+29 \%{ }^{\mathrm{a}, *}$ \\
$\quad$ Yield change & & &
\end{tabular}

Notes: ${ }^{*} p<0.1,{ }^{* *} p<0.05{ }^{\text {a}}$ : since the variable is already expressed as relative change, the percentage change simply refers to the DR estimate. 
Concerning food security, the number of months in the previous year in which a household experienced inadequate food provision (IHFP) ranges from 0 to 8 , with more than half of the sample experiencing one month or more of food shortage (Figure 3). In greater detail, Figure 4 indicates that September was stated as the worst month for food security. However, the estimates show that the $\mathrm{S} 4 \mathrm{~N}$ intervention significantly improves smallholders' food security status, given that both employed indices indicate that program participation may reduce around $10 \%$ of food insecurity as measured via IHFP, and $12 \%$ via the food insecurity dummy.

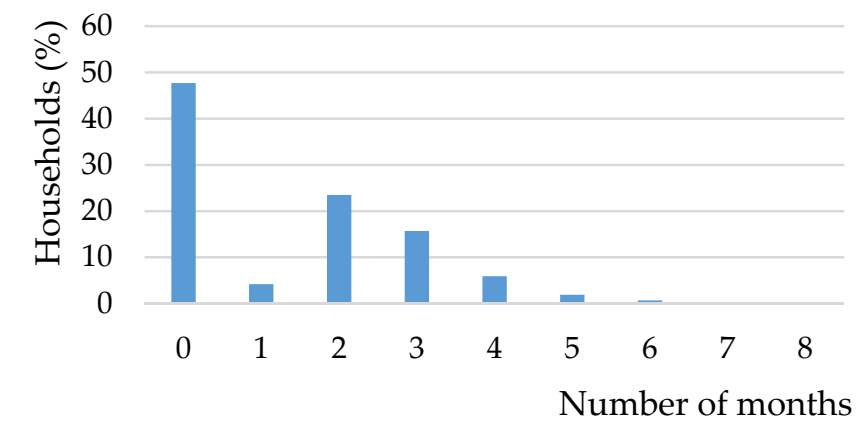

Figure 3. The number of months wherein there was a food shortage in the last 12 months.

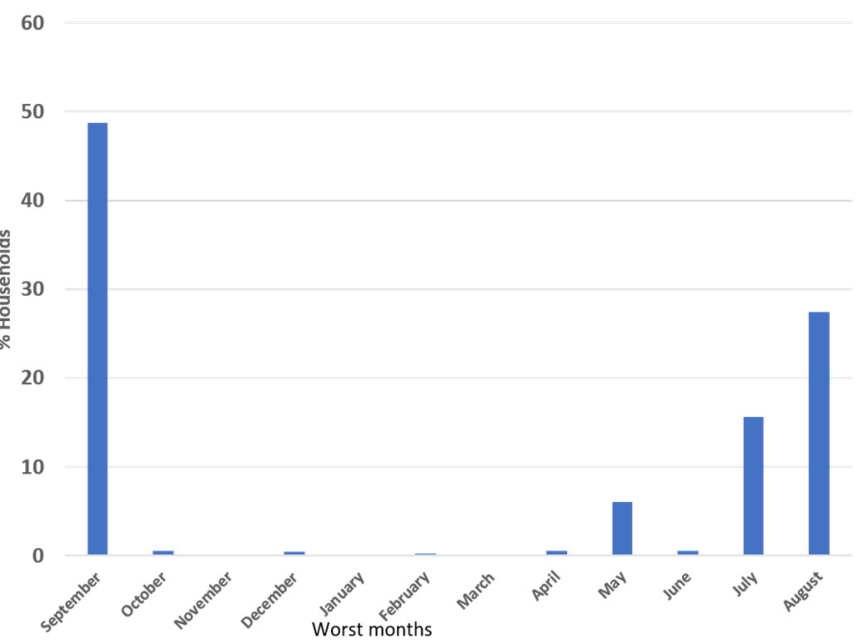

Figure 4. The worst months of the year for food unavailability in the past 12 months.

Data refer to answers given in 2019, after the S4N intervention. September proved to be the worst month for food security. This result is quite expected. The three regions are subject to sub-tropical climates, with one main rainy season (meher) in summer between June and September, and a second shorter period of occasional rainfalls (belg) that may occur from February to May. In such rainfed agricultural system, the most stressful times in terms of food security are the months where the crops are already in the field, i.e., June, July, and December.

It could be that varietal diversification improves household food security because it improves yields. Yields are shown to increase for both $\mathrm{S} 4 \mathrm{~N}$ participants and nonparticipants, but participants had a larger improvement. A possible explanation of the calculated effect could be related to an increased adaptation of the new varieties to specific soil conditions and microclimate. In this regard, most of the respondents declared having expanded the planted area of some varieties in the last five years, planting higher-yielding 
varieties or more resistant ones (Figure 5). However, $\mathrm{S} 4 \mathrm{~N}$ participants did this at a higher rate than non-participant smallholders.

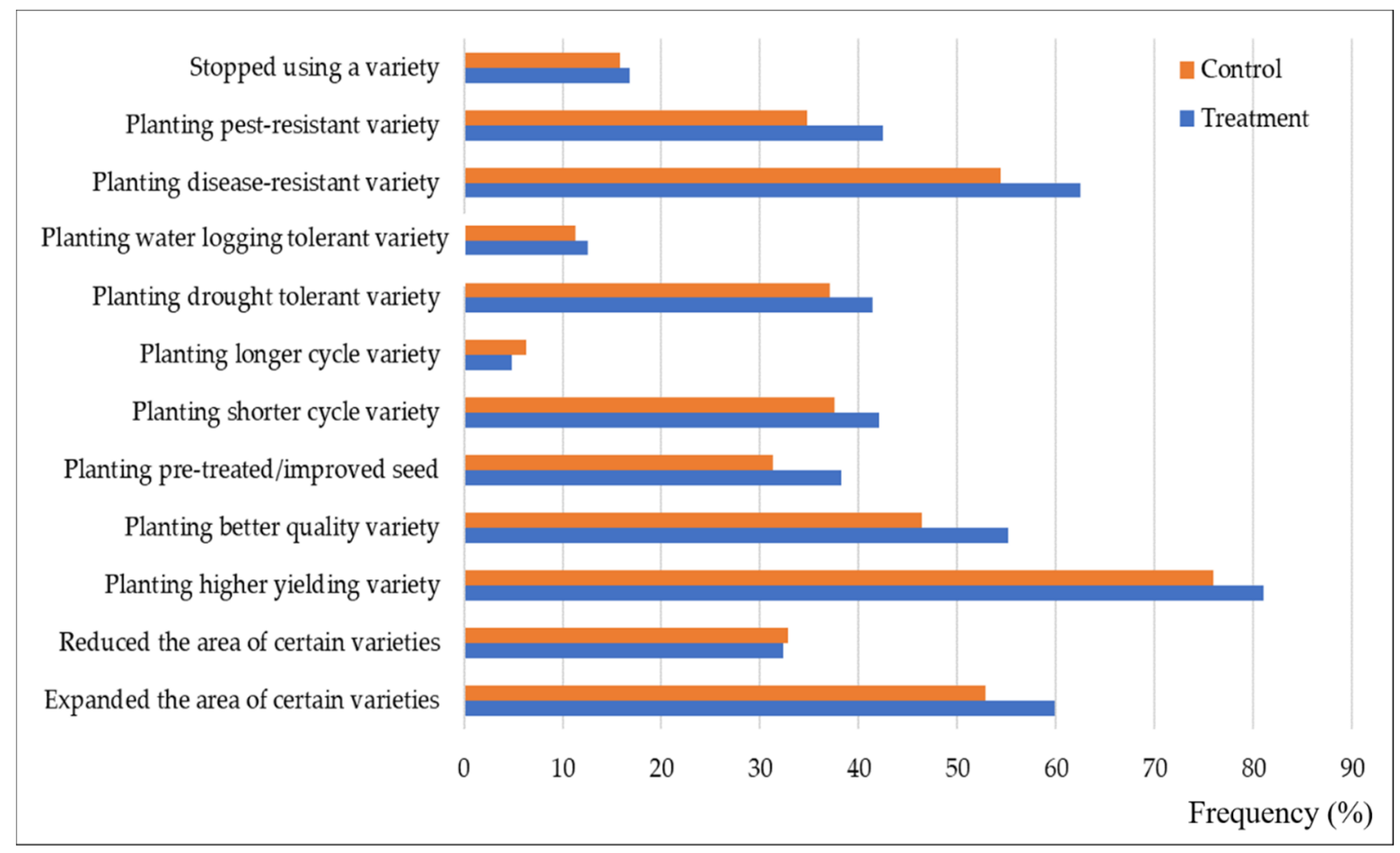

Figure 5. Changes made to crop varieties planted over the last 5 years, by treatment status.

\section{Discussion}

Smallholder farmers in the study areas are aware of the changing climate conditions (especially in terms of temperature and precipitation) [33], and they are undertaking adaptation measures to cope with unpredictable weather conditions. The surveyed households frequently implement microclimatic management techniques such as mulching, agroforestry, and water harvesting, among others. However, varietal diversification constitutes a cheaper and faster alternative strategy to cope with climate change in marginal areas. Indeed, there is a broad consensus on the importance of varietal diversity to increase farmers' capacity to respond to agricultural shocks resulting from highly variable and unpredictable environments. From a sustainable development perspective, varietal diversification is also a cornerstone element for ensuring cost-effective and equitable growth. Indeed, varietal diversification contributes to enhancing soil fertility, stabilizing production and spreading risks across different crop-growing seasons.

On the other hand, there is still debate about the level of agrobiodiversity that is needed to deliver the desired benefits. For instance, another study in Ethiopia reported that varietal richness increases yield stability only for high levels of genetic diversity [54]. Furthermore, it is worth noting that agrobiodiversity generates ecological benefits aside from the individual- or the household-level benefits. Our results showed that varietal diversification through the participatory approach promoted by the $\mathrm{S} 4 \mathrm{~N}$ initiative increases on-farm varietal diversity, as measured by the Simpson diversity index and Margalef species richness index, and enhances households' food security among smallholder farmers in Ethiopia.

The effect on food security is mediated through the yield change associated with the increased adaptation of the new varieties to specific soil conditions and microclimates. Indeed, treated farmers might have knowledge and information on the proposed varieties due to their active participation in the program, while at the same time, they have benefitted from a broader portfolio of varieties. These findings are consistent with Di Falco, 
Chavas and Smale [54], showing that alongside a higher diversification of durum wheat varieties, livelihoods have improved among smallholders in the highlands of Ethiopia.

These results confirm the communal, collaborative nature of these smallholders within such farming systems, which strongly depend on social mechanisms of innovation and imitation. It can be inferred that a participatory approach, such as crowdsourcing, wherein a large number of farmers participate, has great potential to make genetically diverse varieties more easily accessible to smallholders in marginal lands [16,54]. Participatory approaches enhance the capacity of local farmers to test and evaluate the new varieties efficiently and effectively. The method is particularly successful since it automatically considers the heterogeneous needs of farmers, as determined by their prevailing agroecological and market conditions. Indeed, despite living in relatively similar marginal conditions, smallholder farmers in this study do retain considerable differences when it comes to their local ecological knowledge. A participatory approach such as that used in the $\mathrm{S} 4 \mathrm{~N}$ project can unlock these differences and trigger successful diversification strategies.

It should be noted, however, that the effectiveness of such participative modalities is highly influenced by the incentive structures associated with strategies to diversify and maintain a certain level of agrobiodiversity over the long-term. It remains sustainable only if the rural development plans of the local and regional governments favor diversification over monocultures. For example, it is highly recommended that smallholder communities in the marginal highlands of Ethiopia diversify their farming portfolios, to establish a safety net against climate change disasters, even if they are not supported by government strategies. As such, promoting a portfolio approach allows farmers to plant different varieties serving different needs, and should be recommended as good practice.

It is also worth noting that the S4N program has been implemented since 2011 in Ethiopia. Subsequently, over time, the non-participant households are more likely to have access to the new superior varieties supplied by the project through their close social networks and marketing outlets. As part of the S4N implementation strategy, farmers were encouraged to share well-adapted superior varieties after successful multiplication with their neighbors and social networks. This helped ensure the dissemination of the new varieties in the communities, and their long-term, in-situ conservation. Since the time between the implementation and the evaluation of the project is long, it may underestimate the impacts of the project on the households' recovery capacity and wellbeing. Due to the spillover effect, the true effects the program had on participants' households would be biased in comparison with the non-participant households. In other words, we estimated a smaller impact of the program than the true impact that would be found if the nonparticipant households did not have access to or adopt the project varieties.

In addition to accessing genetic resources that are well adapted to their local environment, the adoption of sustainable agricultural practices is equally important to mitigate the adverse impacts of climate change $[7,10,63]$. Over the last 20 years, the sampled households have been increasing their adoption of good agronomic practices when adjusting their agricultural production systems. Although the adoption of sustainable agricultural practices (e.g., intercropping, mulching, terracing, water harvesting) is high among the study households, beneficiary households adopted significantly more than non-beneficiary households. Moreover, over the last five years, the treated groups planted more wheat varieties that are pest- and disease-tolerant, drought-resistant, and more high-yielding compared to the control groups.

\section{Conclusions}

In the face of climate change, the on-farm varietal diversification of crops has been recognized as an effective and environmentally friendly option to improve the capacity of smallholder farmers to respond to shocks and reduce the uncertainty inherent in agricultural production systems linked to climate change. Moreover, varietal diversification has been recognized as a cornerstone contributor to the sustainable development of marginal- 
ized agricultural systems, as it contributes to increasing soil fertility, spreading risks across seasons, and increasing production stability.

In this study, we examined whether households that participated in the S4N initiative improved their on-farm production diversity, recovery capacity, and food security. Using a primary household survey conducted in three regions of Ethiopia, we found that the S4N initiative led to a significant improvement in improving on-farm production diversity, and enhancing food security among smallholder farmers in the study regions. The estimated results are robust under alternative model specifications, and the results were obtained by a doubly robust estimator, which corrects for misspecification in either the treatment or outcome model.

Our study may be limited by not being able to account for the supply side of varieties promoted by the program. For example, farmers may be interested in adopting the new cultivars, but we did not know whether such new varieties were easily accessible to the different socio-economic groups of smallholders, especially those marginalized and poorer farmers.

Author Contributions: Conceptualization, E.G. and F.C.; methodology, M.A.U., M.O.; formal analysis, M.A.U., F.C.; resources, E.G.; data curation, M.O., T.W.; data collection A.Y.K., J.N.M., B.F., M.A., writing—original draft preparation, M.A.U., F.C., M.O.; writing—review and editing, C.F., Y.G.K., D.M.; funding acquisition, C.F. All authors have read and agreed to the published version of the manuscript.

Funding: This review was possible with the contribution of the CGIAR program on Water, Land and Ecosystem (WLE) and the CGIAR program on Climate Change, Agriculture and Food Security (CCAFS), which is carried out with support from the CGIAR Trust Fund and through bilateral funding agreements. For details, please visit https://ccafs.cgiar.org/donors. The views expressed in this document cannot be taken to reflect the official opinions of these organizations.

Institutional Review Board Statement: The study did not require ethical approval.

Informed Consent Statement: Informed consent was obtained from all subjects involved in the study.

Data Availability Statement: The data presented in this study are available on request from the corresponding author. The data are not publicly available yet but will be in due course.

Acknowledgments: Authors wish to thank the participating households for their availability. We thank Vincent Johnson (GreenQuills International) for English editing of this manuscript.

Conflicts of Interest: The authors declare no conflict of interest. The funders had no role in the design of the study; in the collection, analyses, or interpretation of data; in the writing of the manuscript, or in the decision to publish the results.

\section{References}

1. Castells-Quintana, D.; Lopez-Uribe, M.D.; McDermott, T.K.J. Adaptation to climate change: A review through a development economics lens. World Dev. 2018, 104, 183-196. [CrossRef]

2. IPCC. Global Warming of $1.5 \mathrm{c}$ an IPCC Special Report on the Impacts of Global Warming of $1.5 \mathrm{c}$ above Pre-Industrial Levels and Related Global Greenhouse Gas Emission Pathways, in the Context of Strengthening the Global Response to the Threat of Climate Change; IPCC: Geneva, Switzerland, 2019.

3. IPCC. Climate Change 2001: Impacts, Adaptation, and Vulnerability: Summary for Policymakers and Technical Suammary of the Working Griup II Report; Cambridge University Press: Cambridge, UK, 2001.

4. Niang, I.; Ruppel, O.; Abdrabo, M.; Essel, A.; Lennard, C.; Padgham, J.; Urquhart, P. Africa Climate Change 2014: Impacts, Adaptation, and Vulnerability. Part B: Regional Aspects. Contribution of Working Group II to the Fifth Assessment Report of the Intergovernmental Panel on Climate Change; Barros, V.R., Field, C.B., Dokken, D.J., Mastrandrea, M.D., Mach, K.J., Bilir, T.E., Chatterjee, M., Ebi, K.L., Estrada, Y.O., Genova, R.C., et al., Eds.; Cambridge University Press: Cambridge, UK, 2014.

5. Lin, B.B. Resilience in agriculture through crop diversification: Adaptive management for environmental change. Biosci. J. 2011, 61, 183-193. [CrossRef]

6. Below, T.; Artner, A.; Siebert, R.; Sieber, S. Micro-Level Practices to Adapt to Climate Change for African Small-Scale Farmers. A review of Selected Literature; Discussion Paper No. 00953; International Food Policy Research Institute (IFPRI): Washington, DC, USA, 2010.

7. Kabubo-Mariara, J.; Mulwa, R. Adaptation to climate change and climate variability and its implications for household food security in Kenya. Food Secur. 2019, 11, 1289-1304. [CrossRef] 
8. Kahiluoto, H.; Rimhanen, K.; Rötter, R.; Tseganeh, B. Mitigation of climate change to enhance food security: An analytical framework. Forum Dev. Stud. 2012, 39, 51-73. [CrossRef]

9. Altieri, M.A.; Funes-Monzote, F.R.; Petersen, P. Agroecologically efficient agricultural systems for smallholder farmers: Contributions to food sovereignty. Agron. Sustain. Dev. 2012, 32, 1-13. [CrossRef]

10. Bryan, E.; Deressa, T.T.; Gbetibouo, G.A.; Ringler, C. Adaptation to climate change in Ethiopia and South Africa: Options and constraints. Environ. Sci. Policy 2009, 12, 413-426. [CrossRef]

11. McCarthy, J.J.; Canziani, O.F.; Leary, N.A.; Dokken, D.J.; White, K.S. Climate Change 2001: Impacts, Adaptation, and Vulnerability: Contribution of Working Group II to the Third Assessment Report of the Intergovernmental Panel on Climate Change; Cambridge University Press: Cambridge, UK, 2001; Volume 2.

12. Belem, M.; Bazile, D.; Coulibaly, H. Simulating the impacts of climate variability and change on crop varietal diversity in Mali (West-Africa) using agent-based modeling approach. J. Artif. Soc. Soc. Simul. 2018, 21, 18. [CrossRef]

13. Bellon, M.R.; Gotor, E.; Caracciolo, F. Conserving landraces and improving livelihoods: How to assess the success of on-farm conservation projects? Int. J. Agric. Sustain. 2015, 13, 167-182. [CrossRef]

14. Gotor, E.; Bellon, A.; Polar, V.; Caracciolo, F. Assessing the Benefits of Andean Crop Diversity on Farmers' Livelihood: Insights from a Development Programme in Bolivia and Peru. J. Int. Dev. 2017, 29, 877-898. [CrossRef]

15. Bullock, J.M.; Dhanjal-Adams, K.L.; Milne, A.; Oliver, T.H.; Todman, L.C.; Whitmore, A.P.; Pywell, R.F. Resilience and food security: Rethinking an ecological concept. J. Ecol. 2017, 105, 880-884. [CrossRef]

16. Creissen, H.E.; Jorgensen, T.H.; Brown, J.K.M. Increased yield stability of field-grown winter barley (Hordeum vulgare L.) varietal mixtures through ecological processes. Crop Prot. 2016, 85, 1-8. [CrossRef] [PubMed]

17. Di Falco, S.; Chavas, J.P. On crop biodiversity, risk exposure, and food security in the highlands of Ethiopia. Am. J. Agric. Econ. 2009, 91, 599-611. [CrossRef]

18. Smale, M.; Hartell, J.; Heisey, P.W.; Senauer, B. The contribution of genetic resources and diversity to wheat production in the Punjab of Pakistan. Am. J. Agric. Econ. 1998, 80, 482-493. [CrossRef]

19. Widawsky, D.; Rozelle, S. Varietal Diversity and Yield Variability in Chinese Rice Production. In Farmers Genebanks and Crop Breeding: Economic Analyses of Diversity in Wheat Maize and Rice; Smale, M., Ed.; Springer: Dordrecht, The Netherlands, 2000; pp. 159-172.

20. Fadda, C.; van Etten, J. Generating farm-validated variety recommendations for climate adaptation. In The Climate-Smart Agriculture Papers: Investigating the Business of a Productive, Resilient and Low Emission Future; Rosenstock, T.S., Nowak, A., Girvetz, E., Eds.; Springer International Publishing: Cham, Switzerland, 2019; pp. 127-138.

21. Heisey, P.W.; Smale, M.; Byerlee, D.; Souza, E. Wheat rusts and the costs of genetic diversity in the Punjab of Pakistan. Am. J. Agric. Econ. 1997, 79, 726-737. [CrossRef]

22. Mulumba, J.W.; Nankya, R.; Adokorach, J.; Kiwuka, C.; Fadda, C.; De Santis, P.; Jarvis, D.I. A risk-minimizing argument for traditional crop varietal diversity use to reduce pest and disease damage in agricultural ecosystems of Uganda. Agric. Ecosyst. Environ. 2012, 157, 70-86. [CrossRef]

23. Shoffner, A.V.; Tooker, J.F. The potential of genotypically diverse cultivar mixtures to moderate aphid populations in wheat (Triticum aestivum L.). Arthropod-Plant Interact. 2013, 7, 33-43. [CrossRef]

24. Tooker, J.F.; Frank, S.D. Genotypically diverse cultivar mixtures for insect pest management and increased crop yields. J. Appl. Ecol. 2012, 49, 974-985. [CrossRef]

25. Zhu, Y.; Chen, H.; Fan, J.; Wang, Y.; Li, Y.; Chen, J.; Fan, J.; Yang, S.; Hu, L.; Leung, H.; et al. Genetic diversity and disease control in rice. Nature 2000, 406, 718-722. [CrossRef]

26. Di Falco, S.; Veronesi, M.; Yesuf, M. Does adaptation to climate change provide food security? A micro-perspective from Ethiopia. Am. J. Agric. Econ. 2011, 93, 829-846. [CrossRef]

27. Nankya, R.; Mulumba, J.W.; Caracciolo, F.; Raimondo, M.; Schiavello, F.; Gotor, E.; Kikulwe, E.; Jarvis, D.I. Yield perceptions, determinants and adoption impact of on farm varietal mixtures for common bean and banana in Uganda. Sustainability 2017, 9, 1321. [CrossRef]

28. Yorobe, J.M.; Ali, J.; Pede, V.O.; Rejesus, R.M.; Velarde, O.P.; Wang, H.Y. Yield and income effects of rice varieties with tolerance of multiple abiotic stresses: The case of green super rice (GSR) and flooding in the Philippines. Agric. Econ. 2016, 47, 261-271. [CrossRef]

29. Bellon, M.R.; Kotu, B.H.; Azzarri, C.; Caracciolo, F. To diversify or not to diversify, that is the question. Pursuing agricultural development for smallholder farmers in marginal areas of Ghana. World Dev. 2020, 125, 104682. [CrossRef] [PubMed]

30. FAO Statistics Division. FAOSTAT Database. Available online: http://www.fao.org/statistics/en/ (accessed on 1 January 2021).

31. Salami, A.; Kamara, A.B.; Brixiova, Z. Smallholder Agriculture in East Africa: Trends, Constraints and Opportunities; African Development Bank Working Paper No. 105; African Development Bank: Tunis, Tunisia, 2010.

32. Deressa, T.; Hassan, R.M.; Ringler, C. Measuring Ethiopian Farmers' Vulnerability to Climate Change across Regional States; IFPRI Discussion Paper No. 806; International Food Policy Research Institute: Washington, DC, USA, 2008.

33. Mancini, C. Smallholder Farmers' Traditional Knowledge and Wheat Breeding: Linking Genetics to Socioeconomics in the Ethiopian Farming System. Ph.D. Thesis, Sant'Anna school fo Advanced Studies, Pisa, Italy, 2017. 
34. Kabbaj, H.; Sall, A.T.; Al-Abdallat, A.; Geleta, M.; Amri, A.; Filali-Maltouf, A.; Belkadi, B.; Ortiz, R.; Bassi, F.M. Genetic Diversity within a Global Panel of Durum Wheat (Triticum durum) Landraces and Modern Germplasm Reveals the History of Alleles Exchange. Front. Plant Sci. 2017, 8, 1277. [CrossRef]

35. Shiferaw, B.; Kassie, M.; Jaleta, M.; Yirga, C. Adoption of improved wheat varieties and impacts on household food security in Ethiopia. Food Policy 2014, 44, 272-284. [CrossRef]

36. Spielman, D.J.; Byerlee, D.; Alemu, D.; Kelemework, D. Policies to promote cereal intensification in Ethiopia: The search for appropriate public and private roles. Food Policy 2010, 35, 185-194. [CrossRef]

37. Fadda, C.; Mengistu, D.K.; Kidane, Y.G.; Dell'Acqua, M.; Pè, M.E.; Van Etten, J. Integrating Conventional and Participatory Crop Improvement for Smallholder Agriculture Using the Seeds for Needs Approach: A Review. Front. Plant Sci. 2020, 11, 1421. [CrossRef]

38. Mengistu, D.K.; Kiros, A.Y.; Mohammed, J.N.; Tsehaye, Y.; Fadda, C. Exploitation of diversity within farmers' durum wheat varieties enhanced the chance of selecting productive, stable and adaptable new varieties to the local climatic conditions. Plant Genet. Resour. Charact. Util. 2019, 17, 401-411. [CrossRef]

39. Mengistu, D.; Kidane, Y.; Fadda, C.; Pè, M. Genetic diversity in Ethiopian durum wheat (Triticum turgidum var durum) inferred from phenotypic variations. Plant Genet. Resour. Charact. Util. 2018, 16, 39-49. [CrossRef]

40. Mengistu, D.K.; Kidane, Y.G.; Catellani, M.; Frascaroli, E.; Fadda, C.; Pè, M.E.; Dell'Acqua, M. High-density molecular characterization and association mapping in Ethiopian durum wheat landraces reveals high diversity and potential for wheat breeding. Plant Biotechnol. J. 2016, 14, 1800-1812. [CrossRef]

41. Mancini, C.; Kidane, Y.G.; Mengistu, D.K.; Pè, M.E.; Fadda, C.; Dell'Acqua, M. Joining smallholder farmers' traditional knowledge with metric traits to select better varieties of Ethiopian wheat. Sci. Rep. 2017, 7, 9120. [CrossRef]

42. Van Etten, J.; Beza, E.; Calderer, L.; Van Duijvendijk, K.; Fadda, C.; Fantahun, B.; Kidane, Y.G.; Van De Gevel, J.; Gupta, A.; Mengistu, D.K.; et al. First experiences with a novel farmer citizen science approach: Crowdsourcing participatory variety selection through on-farm triadic comparisons of technologies (tricot). Exp. Agric. 2016, 55 (Suppl. 1), 275-296. [CrossRef]

43. van Etten, J.; de Sousa, K.; Aguilar, A.; Barrios, M.; Coto, A.; Dell'Acqua, M.; Fadda, C.; Gebrehawaryat, Y.; van de Gevel, J.; Gupta, A.; et al. Crop variety management for climate adaptation supported by citizen science. Proc. Natl. Acad. Sci. USA 2019, 116, 4194-4199. [CrossRef]

44. Waldman, K.B.; Kerr, J.M.; Isaacs, K.B. Combining participatory crop trials and experimental auctions to estimate farmer preferences for improved common bean in Rwanda. Food Policy 2014, 46, 183-192. [CrossRef]

45. Kidane, Y.G.; Mancini, C.; Mengistu, D.K.; Frascaroli, E.; Fadda, C.; Pè, M.E.; Dell'Acqua, M. Genome Wide Association Study to Identify the Genetic Base of Smallholder Farmer Preferences of Durum Wheat Traits. Front. Plant Sci. 2017, 8, 1230. [CrossRef] [PubMed]

46. vom Brocke, K.; Trouche, G.; Weltzien, E.; Barro-Kondombo, C.P.; Gozé, E.; Chantereau, J. Participatory variety development for sorghum in Burkina Faso: Farmers' selection and farmers' criteria. Field Crops Res. 2010, 119, 183-194. [CrossRef]

47. Asfaw, S.; Scognamillo, A.; Caprera, G.; Sitko, N.; Ignaciuk, A. Heterogeneous impact of livelihood diversification on household welfare: Cross-country evidence from sub-Saharan Africa. World Dev. 2019, 117, 278-295. [CrossRef]

48. Dedehouanou, S.F.A.; McPeak, J. Diversify more or less? Household income generation strategies and food security in rural Nigeria. J. Dev. Stud. 2020, 56, 560-577. [CrossRef]

49. Waha, K.; van Wijk, M.T.; Fritz, S.; See, L.; Thornton, P.K.; Wichern, J.; Herrero, M. Agricultural diversification as an important strategy for achieving food security in Africa. Glob. Chang. Biol. 2018, 24, 3390-3400. [CrossRef]

50. Becerril, J.; Abdulai, A. The impact of improved maize varieties on poverty in Mexico: A propensity score-matching approach. World Dev. 2010, 38, 1024-1035. [CrossRef]

51. Bezu, S.; Kassie, G.T.; Shiferaw, B.; Ricker-Gilbert, J. Impact of improved maize adoption on welfare of farm households in Malawi: A panel data analysis. World Dev. 2014, 59, 120-131. [CrossRef]

52. Jaleta, M.; Kassie, M.; Marenya, P.; Yirga, C.; Erenstein, O. Impact of improved maize adoption on household food security of maize producing smallholder farmers in Ethiopia. Food Secur. 2018, 10, 81-93. [CrossRef]

53. Teferi, E.T.; Kassie, G.T.; Pe, M.E.; Fadda, C. Are farmers willing to pay for climate related traits of wheat? Evidence from rural parts of Ethiopia. Agric. Syst. 2020, 185, 102947. [CrossRef]

54. Di Falco, S.; Chavas, J.-P.; Smale, M. Farmer management of production risk on degraded lands: The role of wheat variety diversity in the Tigray region, Ethiopia. Agric. Econ. 2007, 36, 147-156. [CrossRef]

55. Sibhatu, K.T.; Krishna, V.V.; Qaim, M. Production diversity and dietary diversity in smallholder farm households. Proc. Natl. Acad. Sci. USA 2015, 112, 10657-10662. [CrossRef] [PubMed]

56. Simpson, E.H. Measurement of diversity. Nature 1949, 163, 688. [CrossRef]

57. Furno, M.; Caracciolo, F. Multi-valued Double Robust quantile treatment effect. Empir. Econ. 2020, 58, 2545-2571. [CrossRef]

58. Emsley, R.; Lunt, M.; Pickles, A.; Dunn, G. Implementing Double-robust Estimators of Causal Effects. Stata J. 2008, 8, 334-353. [CrossRef]

59. Caracciolo, F.; Furno, M. Quantile treatment effect and double robust estimators: An appraisal on the Italian labor market. J. Econ. Stud. 2017, 44, 585-604. [CrossRef]

60. Shiferaw, B.A.; Kebede, T.A.; You, L. Technology adoption under seed access constraints and the economic impacts of improved pigeonpea varieties in Tanzania. Agric. Econ. 2008, 39, 309-323. [CrossRef] 
61. Beza, E.; Steinke, J.; van Etten, J.; Reidsma, P.; Fadda, C.; Mittra, S.; Mathur, P.; Kooistra, L. What are the prospects for citizen science in agriculture? Evidence from three continents on motivation and mobile telephone use of resource-poor farmers. PLoS ONE 2017, 12, e0175700. [CrossRef]

62. Quisumbing, A.R.; Haddad, L.; Peña, C. Are women overrepresented among the poor? An analysis of poverty in 10 developing countries. J. Dev. Econ. 2001, 66, 225-269. [CrossRef]

63. Lybbert, T.J.; Sumner, D.A. Agricultural technologies for climate change in developing countries: Policy options for innovation and technology diffusion. Food Policy 2012, 37, 114-123. [CrossRef] 